\begin{tabular}{cc|c}
\hline & $\begin{array}{c}\text { Tarım Bilimleri Dergisi } \\
\text { Tar. Bil. Der. }\end{array}$ & Journal of Agricultural Sciences \\
& $\begin{array}{c}\text { Dergi web sayfası: } \\
\text { www.agri.ankara.edu.tr/dergi }\end{array}$ & $\begin{array}{c}\text { Journal homepage: } \\
\text { www.agri.ankara.edu.tr/journal }\end{array}$ \\
\hline
\end{tabular}

\title{
Effects of Tillage Methods on Penetration Resistance, Bulk Density and Saturated Hydraulic Conductivity in a Clayey Soil Conditions
}

\author{
İsmail ÇELIK ${ }^{\mathrm{a}}$ \\ ${ }^{a}$ Cukurova University, Faculty of Agriculture, Department of Soil Science and Plant Nutrition, 01330 Adana, TURKEY
}

\section{ARTICLE INFO}

Research Article - Agricultural Technologies

DOI: $10.1501 /$ Tarimbil_0000001166

Corresponding author: İsmail ÇELIK, e-mail: icelik@cu.edu.tr, Tel: +90(322) 33866 43/105

Received: 30 May 2011, Received in revised form: 13 September 2011, Accepted: 19 September 2011

\begin{abstract}
Effects of six tillage practices on saturated hydraulic conductivity (HC), soil bulk density (BD), and penetration resistance (PR) were evaluated for a clayey soil (Typic Haploxererts) under semi-arid Mediterranean conditions in a three year study (2006-2009). The experiment was conducted on a randomized complete block design with three replicates. Treatments were: conventional tillage with residue incorporated (CTS), conventional tillage with residue burned (CTB), reduced tillage with heavy tandem disc harrow (RTD), reduced tillage with rotary tiller (RTR), reduced tillage with heavy tandem disc harrow for the first crop + no-tillage for the second crop (RNT), and no tillage (NT). The study was conducted in wheat-corn, wheat-soybean and wheat crop rotations. The tillage effects on $\mathrm{HC}, \mathrm{BD}$ and PR were significant at soil depth of 0-30 $\mathrm{cm}$. The hydraulic conductivity was higher in CTS, and followed by CTB, RTR, RTD, RNT and NT practices, respectively. The hydraulic conductivity values under NT in 2007 and 2008 were $20 \%$ and $30 \%$ lower at $0-30 \mathrm{~cm}$ depth compared with CTS, respectively. The conventional tillage treatments in the semi-arid conditions improved the HC with decreasing BD and PR of the clayey soil. The BD and PR values were higher under NT treatments than the tilled plots and increased with depth. The values of soil compaction indicators were significantly greater under no-tillage and reduced tillage as compared to those under conventional tillage in all soil depths studied.
\end{abstract}

Keywords: Soil bulk density; Hydraulic conductivity; Penetration resistance; Tillage practices

\section{Killi Toprak Koşullarında Toprak İşleme Yöntemlerinin Penetrasyon Direnci, Hacim Ăğırlığı ve Hidrolik İletkenliğe Etkileri}

\section{ESER BİLGISI}

Araştırma Makalesi — Tarım Teknolojileri

Sorumlu Yazar: İsmail ÇELIKK, e-posta: icelik@cu.edu.tr, Tel: +90(322) 338 66 43/105

Geliş tarihi: 30 Mayıs 2011, Düzeltmelerin gelişi: 13 Eylül 2011, Kabul: 19 Eylül 2011

\section{ÖZET}

Altı farklı toprak işleme yönteminin üç yıllık sürede (2006-2009) yarı-kurak Akdeniz iklim koşullarında killi bir toprakta (Typic Haploxererts) doymuş hidrolik iletkenlik, hacim ağırlığı ve penetrasyon direncine etkileri değerlendirilmiştir. Araştırma tesadüf parseller desenine göre üç tekerrürlü olarak yürütülmüştür. Toprak işleme 
uygulamaları olarak: Anızlı geleneksel toprak işleme (CTS), anızları yakılmış geleneksel toprak işleme (CTB), ağır diskli tırmıklı azaltılmış toprak işleme (RTD), rototillerli azaltılmış toprak işleme (RTR), birinci ürün için ağır diskli tırmıklı azaltılmış işleme + ikinci ürün için sıfır toprak işleme (RNT) ve sıfır toprak işleme (NT) yöntemleri kullanılmıştır. Araştırmada buğday-mısır, buğday-soya ve buğday rotasyonu uygulanmıştır. Toprak işleme uygulamalarının farklı derinliklerde doymuş hidrolik iletkenlik, hacim ağırlığı ve penetrasyon dirençleri ölçülmüştür. Toprak işleme uygulamalarının $0-30 \mathrm{~cm}$ toprak derinliğinde hidrolik iletkenlik, hacim ağırlığı ve penetrasyon direncine önemli etkileri belirlenmiştir. Hidrolik iletkenlik en yüksek CTS altında belirlenmiş ve bunu sırasıyla CTB, RTR, RTD, RNT ve NT izlemiştir. 2007 ve 2008 yılında 0-30 cm derinlikteki hidrolik iletkenli değerleri, NT uygulamalarında CTS'e göre sırasıyla \%20 ve \%30 daha düşük bulunmuştur. Geleneksel toprak işleme uygulamaları yarı-kurak iklim koşullarında hacim ağırlığını ve penetrasyon direncini azaltarak hidrolik iletkenliği arttırmıştır. NT uygulamasında elde edilen hacim ağırlığı ve penetrasyon direnç değerleri işlenen topraklara göre daha yüksek bulunmuş ve bu değerler derinlikle birlikte artmıştır. Toprak sıkışmasının göstergeleri olan değerler işlenmeyen ve azaltılmış işleme uygulamaları altında geleneksel işleme uygulamalarına göre bütün derinliklerde önemli ölçüde yüksek bulunmuştur.

Anahtar sözcükler: Toprak hacim ağırlığı; Hidrolik iletkenlik; Penetrasyon direnci; Toprak işleme uygulamaları

(C) Ankara Üniversitesi Ziraat Fakültesi

\section{Introduction}

Conventional tillage is a common practice of Çukurova region located in the Eastern Mediterranean coastal area of Turkey. Double crop rotational systems, wheat-corn or wheatsoybean intensive agricultural practices are usually preferred in the region. The winter crop, wheat is sown in mid-November and harvested at around mid-June. Soil is tilled after wheat harvest for the second crop corn, soybean, cotton or peanut. Farmers mostly burn the stubble to fasten the planting process of second crop. The burnt field is tilled 3 to 5 times with chisel+disc harrow or moulboard plow+disc harrow preceding the first and the second crop harvests. Although, rare examples of conservational tillage methods are applied in the region, no-tillage is not practiced in crop production.

The producers usually till soil to create a loose and uniform seedbed prior to planting. The degree of loosening is closely related to soil texture, soil moisture content, and the type of tillage operation. Some of soil physical properties affected by loosening are bulk density, soil strength, infiltration, water redistribution within the soil profile and the moisture retention (Osunbitan et al 2005). Tillage treatments affect crop growth and yield by altering bulk density, compaction and hydraulic properties of the soils. Desired plant growth depends on rooting ability, nutrient status and accessibility of roots to nutrients, soil aeration, and water availability. Availability of water is restricted severe soil compaction. Plants spend higher energy to extract water from soil due to decreased pore size or lack of pore continuity caused by compaction. Excessive compaction adversely affects crop yields, increase tillage energy requirements, accelerate erosion, and cause inefficient use of water and nutrients due to slow subsoil drainage. Additional field operations and energy may be required to remove soil compaction (Johnson \& Bailey 2002).

The effects of tillage on soil hydraulic properties have been reported by several authors, as shown by the results of Heard et al (1988), Chan \& Heenan (1993), McGarry et al (2000) and Zhang et al (2006). Seventy percent of a field is passed by vehicle traffic in a conventional tillage system (Raper \& Kirby 2005). Soil bulk density and penetration resistance increased with increase in the number of traffic passes while air permeability was decreased with increase traffic intensity (Mamman \& Ohu 1998). The hydraulic properties of soils are affected by soil compaction which leads to soil degradation (Zhang et al 2006).

Reports on tillage effects on hydraulic conductivity are controversy. Some researchers have reported no or negative impact of tillage on soil water characteristics (Obi \& Nnabude 1988; Heard et al 1988), while others found beneficial effects of zero-tillage on soil water retention 
(Blevins et al 1983; Datiri \& Lowery 1991). Significant positive effect of zero-tillage on hydraulic conductivity was reported due to the either greater continuity of pores (Benjamin 1993) or water flow through a very few large pores (Sharratt et al 2006). Bhattacharyya et al (2006) compared the effects of no-tillage and conventional tillage practices in a four-year study, and reported that the hydraulic conductivity values were higher in no-tillage than tilled soils. However, Heard et al (1988) reported significant higher hydraulic conductivities in tilled soils. Karlen et al (1994) reported no significant difference in saturated hydraulic conductivity under no-tillage corn with stover maintained, removed, and doubled in a 10-year study of silt loams. The inconsistent results of soil physical and hydraulic properties under different tillage systems may be related to the transitory nature of soil structure after tillage, site history, initial and final water content, the time of sampling and the extent of soil disturbances (Azooz \& Arshad 1996).

Soil compaction is an increase in the density of soil and reduction in porosity, associated with an increase in strength and a reduction in hydraulic conductivity. Soil compaction causes problems including poor aeration, excessive soil strength limiting root growth, drainage, excessive runoff and erosion. Sometimes, however, compaction is desirable, because it can lead to improved seed-soil contact, and hence better germination and growth of the seedling (Radford $\&$ Nielsen 1985). Green et al (2003) noted that field traffic had significant effects on soil compaction and related hydraulic properties in some soils and climates, while in others, landscape and temporal variations were so strong that any effects of wheel tracks were relatively negligible. Sillon et al (2003) found that a calcareous soil had a higher hydraulic conductivity, across the whole range of water ratios tested, following a compaction treatment.

Trends in soil bulk density are generally considered a rough approximation of soil structural changes (Liebig et al 2004). Several studies have informed higher bulk density under no-tillage compared with tilled soil (Klute 1982; $\mathrm{Wu}$ et al 1992). The soil bulk density decreased with the degree of soil manipulation during tillage practices. Significantly lower soil bulk density in conventional tillage system could be due to the incorporation of crop residues by tillage to the surface soil depth (Bhattacharyya et al 2006).

The effects of tillage practices on soil physical properties such as aggregation, bulk density, porosity, hydraulic properties, soil compaction, and water retention are variable. Information on changes in soil hydraulic conductivity and soil strength properties, especially in heavy clayey soil, due to tillage practices is limited. Therefore, this study was performed to determine the effects of conventional, reduced and no-tillage practices on saturated hydraulic conductivity, soil bulk density and penetration resistance in wheat-cornwheat-soybean rotations in a clay soil under semiarid climatic conditions. Besides, comparison of tillage practices may be of great help for the longterm sustainability of agricultural ecosystems under semi-arid climatic conditions for Mediterranean.

\section{Materials and Methods}

\subsection{Experimental site}

A field experiment was carried out in the period from 2006 to 2009 at the Agricultural Experimental Station $\left(37^{\circ} 00^{\prime} 54^{\prime \prime}\right.$ N, 35 $21^{\prime} 27^{\prime \prime}$ E; $32 \mathrm{~m}$ above sea level) of the Cukurova University, Adana, Turkey. The prevailing climate of study area is Mediterranean with a long-term (30 years) mean annual temperature of $20{ }^{\circ} \mathrm{C}$ and precipitation is around 670 where the long-term mean annual potential evapotranspiration is 1500 $\mathrm{mm} \mathrm{yr}^{-1}$. The summers are hot and dry and the winters are rainy and mild. The annual mean temperature between 2006 and 2009 was $19.2{ }^{\circ} \mathrm{C}$, the relative humidity was $70 \%$, and the precipitation was $563 \mathrm{~mm}$. The experiment was on the Arik clay with a slope of about $1 \%$. The soil had $50 \%$ clay, $32 \%$ silt and $18 \%$ sand at the depth 0-30 cm (Celik et al 2009), and was classified as Typic Haploxererts (Soil Survey 
Staff 1999). The soil had a $\mathrm{pH}$ of 7.82 , bulk density of $1.31 \mathrm{Mg} \mathrm{m}^{-3}$, total organic carbon of $8.76 \mathrm{~g} \mathrm{~kg}^{-1}, \mathrm{CaCO}_{3}$ of $244 \mathrm{~g} \mathrm{~kg}^{-1}$, and electrical conductivity of $0.15 \mathrm{dS} \mathrm{m}^{-1}$ (Celik et al 2009).

\subsection{Experimental design and tillage systems}

The study area has been used for continuous wheat (Triticum aestivum L.) production with conventional tillage for more than 30 years. After harvesting wheat in June 2006 field was prepared for the trial. The experiment was a randomized complete block design with three replications. The treatments were conventional tillage with residue incorporated in soil (CTS), conventional tillage with residue burned (CTB), reduced tillage with heavy tandem disc-harrow (RTD), reduced tillage with rotary tiller (RTR), reduced tillage with heavy tandem disc harrow for the first crop + notillage for the second crop (RNT), and no tillage (NT). The plots were of $12-\mathrm{m}$ width and $40-\mathrm{m}$ length $\left(480 \mathrm{~m}^{2}\right)$. The details of the six different tillage and sowing methods used in the study are given in Table 1.

The rotations of winter wheat (Triticum aestivum L.)-corn (Zea Mays L), wheat-soybean (Glycine max. L.) and wheat were applied in all treatments from 2006 to 2009 . The crop rotation was wheat-corn in the 2006-2007, wheat-soybean in the 2007-2008 and wheat in the 2008-2009 growing seasons, respectively. In each growing season, the first crop was winter wheat and the second crop was corn and soybean in turn. The growing period of winter wheat was from November to the first week of June and for corn and soybean was from the second week of June to the first week of October.

In the conventional tillage methods (CTS and CTB), following wheat harvest, farmers burn the residues, and plough the soil as early as possible for a second crop corn or soybean. They apply similar practices after the second crop to sow winter wheat. Some farmers till the soil immediately after harvesting the second crop while others leave residues on the soil surface for a while and then plough the soil with a moldboard. In the CTS, RTD and RTR practices, soil was tilled after the first and second crop and residues were shredded on the plots. The residues of the first and second crops were shredded and left on the soil surface in NT system. Whereas, the stovers of the second crop were shredded, and soil was tilled in RNT where the stubbles of the first crop were only chopped and left on soil surface (Table 1).

The total herbicide (500 $\mathrm{g} \mathrm{ha}^{-1}$ Glyphosate) was used to control weeds in the NT and RNT treatments two weeks prior to sowing. Composed NP-fertilizers were applied in the seedbed at rates of $172 \mathrm{~kg} \mathrm{~N} \mathrm{ha}^{-1}$ and $55 \mathrm{~kg} \mathrm{P}_{2} \mathrm{O}_{5} \mathrm{ha}^{-1}$ for wheat, $250 \mathrm{~kg} \mathrm{~N} \mathrm{ha}^{-1}$ and $60 \mathrm{~kg} \mathrm{P}_{2} \mathrm{O}_{5} \mathrm{ha}^{-1}$ for corn, and $120 \mathrm{~kg} \mathrm{~N} \mathrm{ha}^{-1}$ and $40 \mathrm{~kg} \mathrm{P}_{2} \mathrm{O}_{5} \mathrm{ha}^{-1}$ for soybean. Winter wheat was sown in the first weeks of November 2006, 2007, and 2008 at seeding rate of $240 \mathrm{~kg} \mathrm{ha}^{-1}$ and harvested in the first weeks of June 2007, 2008, and 2009. Corn and soybean were sown in the third weeks of June and harvested in the second weeks of October 2007 and 2008. The seeding rate of wheat was $240 \mathrm{~kg}$ $\mathrm{ha}^{-1}$ in a row distance of $14 \mathrm{~cm}$. Corn and soybean were sown at seeding rates of 8.4 and 23.6 plants per $\mathrm{m}^{-2}$, respectively. The row distance was $70 \mathrm{~cm}$ for corn and soybean, and seed spacings in a row were $17 \mathrm{~cm}$ for corn and $6 \mathrm{~cm}$ for soybean. Corn and soybean were sprinkler-irrigated once in every 13-day and nine times totally during the growing period. The amount of water applied for each irrigation was identical for all treatments, and no irrigation water was applied to the wheat.

\subsection{Soil sampling and analysis}

In order to determine the effects of tillage practices on soil properties, disturbed and undisturbed samples were collected three times throughout the research period from $0-10 \mathrm{~cm}, 10$ $20 \mathrm{~cm}$ and $20-30 \mathrm{~cm}$ depths. The first samples were taken in June 2006 following the establishment of the plots. The second and the third samples were taken immediately after the harvest of the second crop in the first weeks of October 2007 and 2008, respectively.

Initial bulk density, saturated hydraulic conductivity and penetration resistance of experimental field (June 2006) were given in Table 2. The texture of the research area was 
Table 1-Tillage methods, depth of tillage, and type of the equipments used in the study Çizelge 1-Toprak işleme yöntemleri, kullanılan ekipman çeşitleri ve işleme derinlikleri

\begin{tabular}{|c|c|c|}
\hline Tillage Methods & Winter wheat (November 2006, 2007, 2008) & $\begin{array}{l}\text { Second crop maize and soybean } \\
\text { (June } 2007,2008 \text { ) }\end{array}$ \\
\hline $\begin{array}{l}\text { Conventional tillage } \\
\text { with residue } \\
\text { incorporated in the } \\
\text { soil (CTS) }\end{array}$ & $\begin{array}{l}\text { Stover chopping of second crop } \\
\text { Mouldboard plough }\left(30-33 \mathrm{~cm}^{\mathrm{a}}, 6.5-7.0 \mathrm{~km} \mathrm{~h}^{-1} \mathbf{b}\right) \\
\text { Disc harrow }\left(2 \text { passes, } 13-15 \mathrm{~cm}, 8-9 \mathrm{~km} \mathrm{~h}^{-1}\right) \\
\text { Float }\left(2 \text { passes, } 8-9 \mathrm{~km} \mathrm{~h}^{-1}\right) \\
\text { Drill }\left(4 \mathrm{~cm}, 5.5-6.0 \mathrm{~km} \mathrm{~h}^{-1}\right)\end{array}$ & $\begin{array}{l}\text { Stubble chopping of wheat } \\
\text { Heavy tandem disc harrow }\left(18-20 \mathrm{~cm}, 7-8 \mathrm{~km} \mathrm{~h}^{-1}\right) \\
\text { Disc harrow }\left(2 \text { passes, } 13-15 \mathrm{~cm}, 8-9 \mathrm{~km} \mathrm{~h}^{-1}\right) \\
\text { Float }\left(2 \text { passes, } 8-9 \mathrm{~km} \mathrm{~h}^{-1}\right) \\
\text { Planter }\left(8 \mathrm{~cm}, 4-5 \mathrm{~km} \mathrm{~h}^{-1}\right)\end{array}$ \\
\hline $\begin{array}{l}\text { Conventional tillage } \\
\text { with residue burned } \\
\text { (CTB) }\end{array}$ & $\begin{array}{l}\text { Stover burning of second crop } \\
\text { Mouldboard plough }\left(30-33 \mathrm{~cm}, 6.5-7.0 \mathrm{~km} \mathrm{~h}^{-1}\right) \\
\text { Disc harrow }\left(2 \text { passes, } 13-15 \mathrm{~cm}, 8-9 \mathrm{~km} \mathrm{~h}^{-1}\right) \\
\text { Float }\left(2 \text { passes, } 8-9 \mathrm{~km} \mathrm{~h}^{-1}\right) \\
\text { Drill }\left(4 \mathrm{~cm}, 5.5-6.0 \mathrm{~km} \mathrm{~h}^{-1}\right)\end{array}$ & $\begin{array}{l}\text { Stubble burning of wheat } \\
\text { Chisel plow }\left(35-38 \mathrm{~cm}, 6.5-7.0 \mathrm{~km} \mathrm{~h}^{-1}\right) \\
\text { Disc harrow }\left(2 \text { passes, } 13-15 \mathrm{~cm}^{-1} 8-9 \mathrm{~km} \mathrm{~h}^{-1}\right) \\
\text { Float }\left(2 \text { passes, } 8-9 \mathrm{~km} \mathrm{~h}^{-1}\right) \\
\text { Planter }\left(8 \mathrm{~cm}, 4-5 \mathrm{~km} \mathrm{~h}^{-1}\right)\end{array}$ \\
\hline $\begin{array}{l}\text { Reduced tillage with } \\
\text { heavy tandem disc } \\
\text { harrow (RTD) }\end{array}$ & $\begin{array}{l}\text { Stover chopping of second crop } \\
\text { Heavy tandem disc harrow }\left(2 \text { passes, } 18-20 \mathrm{~cm}, 7-8 \mathrm{~km} \mathrm{~h}^{-1}\right) \\
\text { Float }\left(2 \text { passes, } 8-9 \mathrm{~km} \mathrm{~h}^{-1}\right) \\
\text { Drill }\left(4 \mathrm{~cm} 5.5-6.0 \mathrm{~km} \mathrm{~h}^{-1}\right)\end{array}$ & $\begin{array}{l}\text { Stubble chopping of wheat } \\
\text { Rotary tiller }\left(13-15 \mathrm{~cm}, 1.5-2.0 \mathrm{~km} \mathrm{~h}^{-1}\right) \\
\text { Float }\left(2 \text { passes, } 8-9 \mathrm{~km} \mathrm{~h}^{-1}\right) \\
\text { Planter }\left(8 \mathrm{~cm}, 4-5 \mathrm{~km} \mathrm{~h}^{-1}\right)\end{array}$ \\
\hline $\begin{array}{l}\text { Reduced tillage with } \\
\text { rotary tiller (RTR) }\end{array}$ & $\begin{array}{l}\text { Stover chopping of second crop } \\
\text { Rotary tiller }\left(13-15 \mathrm{~cm}, 1.5-2.0 \mathrm{~km} \mathrm{~h}^{-1}\right) \\
\text { Float }\left(2 \text { passes, } 8-9 \mathrm{~km} \mathrm{~h}^{-1}\right) \\
\text { Drill }\left(4 \mathrm{~cm}, 5.5-6.0 \mathrm{~km} \mathrm{~h}^{-1}\right)\end{array}$ & $\begin{array}{l}\text { Stubble chopping of wheat } \\
\text { Rotary tiller }\left(13-15 \mathrm{~cm}, 1.5-2.0 \mathrm{~km} \mathrm{~h}^{-1}\right) \\
\text { Float }\left(2 \text { passes, } 8-9 \mathrm{~km} \mathrm{~h}^{-1}\right) \\
\text { Planter }\left(8 \mathrm{~cm}, 4-5 \mathrm{~km} \mathrm{~h}^{-1}\right)\end{array}$ \\
\hline $\begin{array}{l}\text { Reduced tillage with } \\
\text { heavy tandem disc } \\
\text { harrow + no-tillage } \\
(\mathrm{RNT})\end{array}$ & $\begin{array}{l}\text { Stover chopping of second crop } \\
\text { Heavy tandem disc harrow }\left(18-20 \mathrm{~cm}, 7-8 \mathrm{~km} \mathrm{~h}^{-1}\right) \\
\text { Float }\left(2 \text { passes, } 8-9 \mathrm{~km} \mathrm{~h}^{-1}\right) \\
\text { Drill }\left(4 \mathrm{~cm}, 5.5-6.0 \mathrm{~km} \mathrm{~h}^{-1}\right)\end{array}$ & $\begin{array}{l}\text { Stubble chopping of wheat } \\
\text { Herbicide treatment } \\
\text { No-till planter }\left(8 \mathrm{~cm}, 4.0-4.5 \mathrm{~km} \mathrm{~h}^{-1}\right)\end{array}$ \\
\hline $\begin{array}{l}\text { No-tillage } \\
\text { (NT) }\end{array}$ & $\begin{array}{l}\text { Stover chopping of second crop } \\
\text { Herbicide treatment } \\
\text { No-till drill }\left(4 \mathrm{~cm}, 5.0-5.5 \mathrm{~km} \mathrm{~h}^{-1}\right)\end{array}$ & $\begin{array}{l}\text { Stubble chopping of wheat } \\
\text { Herbicide treatment } \\
\text { No-till planter }\left(8 \mathrm{~cm}, 4.0-4.5 \mathrm{~km} \mathrm{~h}^{-1}\right)\end{array}$ \\
\hline
\end{tabular}

a) Figure is average working depth of the equipments, and ${ }^{\text {b) }}$ figure is average working speed of the equipments

homogeneous throughout the parcels, and no significant differences were determined at the three depths. But, the mean bulk density (at depth $10-20 \mathrm{~cm}$ ) and penetration resistance (at depth 10$30 \mathrm{~cm}$ ) values of tillage treatments were different. The mean bulk density, hydraulic conductivity and penetration resistance values of parcels for treatments were ranged between 1.20 and $1.44 \mathrm{Mg}$ $\mathrm{m}^{-3}, 7.33$ and $9.05 \times 10^{-6} \mathrm{~m} \mathrm{~s}^{-1}$, and 0.601 and $0.984 \mathrm{MPa}$ for $10-20 \mathrm{~cm}$ and $20-30 \mathrm{~cm}$ depths, respectively.

The twenty four undisturbed samples per tillage treatment were collected. In order to sample RNT and NT parcels, the residue on the soil surface was cleaned. Undisturbed soil samples were taken using a steel cylinder of 100 $\mathrm{cm}^{3}$ volume $(5 \mathrm{~cm}$ in diameter, and $5.1 \mathrm{~cm}$ in height). Bulk density and saturated hydraulic conductivity were determined from undisturbed soil samples. The bulk density was measured by the core method (Blake \& Hartge 1986), and saturated hydraulic conductivity was determined by the falling-head method (Klute \& Dirksen 1986).

Soil penetration resistance was determined by a hand-pushing electronic cone penetrometer (Eijkelkamp Penetrologger 06.15.SA) following ASAE standard procedures (ASAE 1994), using a cone with $2 \mathrm{~cm}^{2}$ base area, $60^{\circ}$ included angle and $80 \mathrm{~cm}$ driving shaft; readings were recorded at 10 $\mathrm{mm}$ intervals. The measurements were performed at 6 points in each plot, following the maize and soybean were harvested. Soil moisture content and penetration resistance were measured at the same time. In order to determine the soil moisture content, undisturbed soil samples were taken using a steel cylinder of $100 \mathrm{~cm}^{3}$ volume from each parcel and depths of 0-15, 15-30 and 30-45 $\mathrm{cm}$. Soil gravimetric moisture content was calculated from the weight difference between wet 
Table 2-Initial values of some soil properties before different tillage treatments (June 2006) Çizelge 2-Farklı toprak işleme uygulamalarından önce başlangıçtaki (2006) bazı toprak özellikleri

\begin{tabular}{lcrcc}
\hline $\begin{array}{l}\text { Tillage } \\
\text { Treatments }\end{array}$ & $\begin{array}{c}\text { Depth, } \\
\mathrm{cm}\end{array}$ & $\begin{array}{c}\text { Bulk density, Mg } \\
\mathrm{m}^{-3}\end{array}$ & $\begin{array}{c}\text { Hydraulic } \\
\text { conductivity, } 10^{-6} \mathrm{~m} \mathrm{~s}^{-1}\end{array}$ & $\begin{array}{c}\text { Penetration } \\
\text { resistance, MPa }\end{array}$ \\
\hline CTS & $0-10$ & $1.23 \pm 0.07^{\dagger} \mathrm{a}^{\mathbf{s}}$ & $8.04 \pm 2.53 \mathrm{a}$ & $0.605 \pm 0.23 \mathrm{a}$ \\
CTB & $0-10$ & $1.22 \pm 0.01 \mathrm{a}$ & $7.94 \pm 2.38 \mathrm{a}$ & $0.601 \pm 0.06 \mathrm{a}$ \\
RTD & $0-10$ & $1.20 \pm 0.09 \mathrm{a}$ & $8.14 \pm 2.68 \mathrm{a}$ & $0.624 \pm 0.06 \mathrm{a}$ \\
RTR & $0-10$ & $1.25 \pm 0.04 \mathrm{a}$ & $7.96 \pm 3.01 \mathrm{a}$ & $0.627 \pm 0.16 \mathrm{a}$ \\
RNT & $0-10$ & $1.23 \pm 0.05 \mathrm{a}$ & $8.08 \pm 1.93 \mathrm{a}$ & $0.676 \pm 0.12 \mathrm{a}$ \\
NT & $0-10$ & $1.24 \pm 0.03 \mathrm{a}$ & $8.01 \pm 2.97 \mathrm{a}$ & $0.645 \pm 0.02 \mathrm{a}$ \\
\hline CTS & $10-20$ & $1.30 \pm 0.06 \mathrm{ab}$ & $8.18 \pm 1.96 \mathrm{a}$ & $0.890 \pm 0.11 \mathrm{~b}$ \\
CTB & $10-20$ & $1.41 \pm 0.01 \mathrm{a}$ & $8.70 \pm 2.55 \mathrm{a}$ & $0.830 \pm 0.16 \mathrm{c}$ \\
RTD & $10-20$ & $1.28 \pm 0.01 \mathrm{~b}$ & $8.50 \pm 3.26 \mathrm{a}$ & $0.750 \pm 0.20 \mathrm{~d}$ \\
RTR & $10-20$ & $1.30 \pm 0.05 \mathrm{ab}$ & $8.54 \pm 2.71 \mathrm{a}$ & $0.846 \pm 0.41 \mathrm{c}$ \\
RNT & $10-20$ & $1.31 \pm 0.05 \mathrm{ab}$ & $8.48 \pm 3.17 \mathrm{a}$ & $0.820 \pm 0.05 \mathrm{c}$ \\
NT & $10-20$ & $1.37 \pm 0.07 \mathrm{ab}$ & $9.05 \pm 2.80 \mathrm{a}$ & $0.935 \pm 0.08 \mathrm{a}$ \\
\hline CTS & $20-30$ & $1.32 \pm 0.01 \mathrm{a}$ & $7.36 \pm 2.81 \mathrm{a}$ & $0.984 \pm 0.32 \mathrm{a}$ \\
CTB & $20-30$ & $1.44 \pm 0.07 \mathrm{a}$ & $7.66 \pm 2.53 \mathrm{a}$ & $0.964 \pm 0.16 \mathrm{a}$ \\
RTD & $20-30$ & $1.35 \pm 0.02 \mathrm{a}$ & $7.45 \pm 3.61 \mathrm{a}$ & $0.775 \pm 0.17 \mathrm{c}$ \\
RTR & $20-30$ & $1.40 \pm 0.03 \mathrm{a}$ & $7.70 \pm 2.73 \mathrm{a}$ & $0.852 \pm 0.32 \mathrm{bc}$ \\
RNT & $20-30$ & $1.36 \pm 0.05 \mathrm{a}$ & $7.59 \pm 2.43 \mathrm{a}$ & $0.892 \pm 0.09 \mathrm{ab}$ \\
NT & $20-30$ & $1.40 \pm 0.04 \mathrm{a}$ & $7.33 \pm 2.61 \mathrm{a}$ & $0.892 \pm 0.09 \mathrm{ab}$ \\
\hline
\end{tabular}

* CTS: Conventional tillage with residue, CTB: Conventional tillage with residues burned, RTD: Reduced tillage with heavy tandem disc harrow, RTR: Reduced tillage with rotary tiller, RNT: Reduced tillage with heavy tandem disc harrow for the fist crop+no-tillage for the second crop, NT: No tillage.

${ }^{\dagger}$ The numbers following \pm indicate standard deviation.

$\stackrel{\mathrm{a}-\mathrm{d}}{\mathrm{i}}$ Values in a same column followed by different letter are significantly different (Tukey, $P \leq 0.05$ ).

and oven dry samples $\left(72 \mathrm{~h}\right.$ at $\left.105^{\circ} \mathrm{C}\right)$. The volumetric moisture content was calculated by dividing the gravimetric moisture content to the soil volume of $100 \mathrm{~cm}^{3}$. The average moisture contents (volumetric) were given in Table 3. During the measurements of penetration resistance, soils were at approximately permanent wilting point and cracks on soil surface were not detected in parcels.

\subsection{Statistical analysis}

Univariate analysis of variance (ANOVA) was applied to assess the effects of tillage treatments on saturated hydraulic conductivity, soil bulk density and penetration resistance and for variances among soil tillage and depth. Following the ANOVA test, the Tukey test was performed to compare differences in means of the parameters at significance level of $P \leq 0.05$. The statistical analyses were performed using SPSS software (version 9.0).

\section{Results and Discussion}

\subsection{Soil bulk density}

The tillage applications did not lead significant differences on bulk density in the first year (2007) of the experiment however, bulk density in 2008 was significantly different $(P<0.01)$ (Table 4$)$. The soil depth affected statistically on bulk density both of 2007 and 2008. Bulk density of $20-30 \mathrm{~cm}$ soil depth was greater compared to that of $0-10 \mathrm{~cm}$ and $10-20 \mathrm{~cm}$ depths, Interaction effects of tillage treatment and soil dept on bulk density were not significant for 2007 (maize) and 2008 (soybean) $(P . \geq 0.05)$

The lowest bulk density values were obtained with conventional tillage with residue incorporation in soil (CTS) and conventional tillage with residue burning (CTB) applications. The highest bulk density values were obtained with NT and RNT, respectively (Table 4). 
Table 3-Means of soil moisture content (volumetric percentage) at the time of penetration measurements for each year and depth

Çizelge 3-Penatrasyon ölçümlerinin yapıldı̆̆ı andaki toprak nem içerikleri (\% hacimsel)

\begin{tabular}{lccccccccc}
\hline Tillage & \multicolumn{3}{c}{ Initially (June 2006) } & \multicolumn{3}{c}{ Maize (October 2007) } & \multicolumn{3}{c}{ Soybean (October 2008) } \\
\cline { 2 - 10 } Treatments & $0-15 \mathrm{~cm}$ & $15-30 \mathrm{~cm}$ & $30-45 \mathrm{~cm}$ & $0-15 \mathrm{~cm}$ & $15-30 \mathrm{~cm}$ & $30-45 \mathrm{~cm}$ & $0-15 \mathrm{~cm}$ & $15-30 \mathrm{~cm}$ & $30-45 \mathrm{~cm}$ \\
\hline CTS & $23.32 \mathrm{a}$ & $24.72 \mathrm{a}$ & $25.90 \mathrm{a}$ & $24.96 \mathrm{a}$ & $25.57 \mathrm{a}$ & $26.48 \mathrm{a}$ & $22.27 \mathrm{a}$ & $22.61 \mathrm{a}$ & $23.44 \mathrm{a}$ \\
CTB & $23.69 \mathrm{a}$ & $24.69 \mathrm{a}$ & $25.03 \mathrm{a}$ & $25.27 \mathrm{a}$ & $26.18 \mathrm{a}$ & $27.28 \mathrm{a}$ & $22.64 \mathrm{a}$ & $23.07 \mathrm{a}$ & $24.08 \mathrm{a}$ \\
RTD & $23.68 \mathrm{a}$ & $24.87 \mathrm{a}$ & $25.44 \mathrm{a}$ & $25.54 \mathrm{a}$ & $26.49 \mathrm{a}$ & $27.73 \mathrm{a}$ & $23.09 \mathrm{a}$ & $23.67 \mathrm{a}$ & $23.42 \mathrm{a}$ \\
RTR & $22.66 \mathrm{a}$ & $24.09 \mathrm{a}$ & $24.84 \mathrm{a}$ & $25.55 \mathrm{a}$ & $26.36 \mathrm{a}$ & $27.77 \mathrm{a}$ & $22.44 \mathrm{a}$ & $23.16 \mathrm{a}$ & $23.77 \mathrm{a}$ \\
RNT & $23.42 \mathrm{a}$ & $24.82 \mathrm{a}$ & $25.39 \mathrm{a}$ & $25.60 \mathrm{a}$ & $26.23 \mathrm{a}$ & $27.61 \mathrm{a}$ & $22.24 \mathrm{a}$ & $22.94 \mathrm{a}$ & $23.76 \mathrm{a}$ \\
NT & $23.36 \mathrm{a}$ & $24.69 \mathrm{a}$ & $25.79 \mathrm{a}$ & $25.63 \mathrm{a}$ & $26.96 \mathrm{a}$ & $27.74 \mathrm{a}$ & $22.42 \mathrm{a}$ & $23.16 \mathrm{a}$ & $23.60 \mathrm{a}$ \\
\hline
\end{tabular}

* CTS: Conventional tillage with residue. CTB: Conventional tillage with residues burned. RTD: Reduced tillage with heavy tandem disc harrow. RTR: Reduced tillage with rotary tiller. RNT: Reduced tillage with heavy tandem disc harrow for the fist crop+no-tillage for the second crop. NT: No tillage.

$\stackrel{\mathrm{a}-\mathrm{a}}{ }$ : Values in a same column followed by the same letter are not significantly different (Tukey, $P \geq 0.05$ ).

Generally, soil bulk density was increased in NT and RNT systems, while decreased in conventional tillage (CTS and CTB) systems. Kanwar (1989) and Meek et al (1992) reported that tillage systems have altered bulk density and porosity of soils. Decreasing the number, intensity and depth of tillage induced to obtain higher bulk density values (Table 4).

The increases in bulk density of the soil with no-tillage treatments have previously been reported by Xu \& Mermoud (2001). Contrasting results have been reported for the effects of soil tillage systems on bulk density. Greater bulk density values under conventional tillage systems were reported when compared to no-tillage (Dao 1996; Roscoe \& Buurman 2003).

When the results obtained at the end of the study (2008) were compared, bulk density values under NT were $11.0-8.0 \%, 10.0-7.0 \%$ and $10.0-$ $8.0 \%$ higher than those under CTS and CTB for 0 $10 \mathrm{~cm}, 10-20 \mathrm{~cm}$ and $20-30 \mathrm{~cm}$ respectively (Table 4). Similarly, Dam et al (2005) found that bulk density at $0-10 \mathrm{~cm}$ was $10 \%$ higher in notillage $\left(1.37 \mathrm{Mg} \mathrm{m}^{-3}\right)$ than in conventional tillage $\left(1.23 \mathrm{Mg} \mathrm{m}^{-3}\right)$. Tebrügge \& Düring (1999) reported bulk density of 1.2 to $1.35 \mathrm{Mg} \mathrm{m}^{-3}$ under inversion tillage and 1.4 to $1.5 \mathrm{Mg} \mathrm{m}^{-3}$ under notillage. Lower bulk density obtained in CTS and CTB than in RNT and NT might be attributed to short term loosening effect of tillage and incorporation of crop residues into deeper soil (Bhattacharyya et al 2006).

\subsection{Saturated hydraulic conductivity (HC)}

The effects of tillage systems and the soil depth on $\mathrm{HC}$ were significantly different $(P<0.01)$ in 2007 and 2008 (Table 4). Tillage $\times$ depth interaction effects on the $\mathrm{HC}$ was found statistically significant $(P<0.001)$ for 2007 , but not $(P=0.054)$ for 2008 (Table 4). Saturated hydraulic conductivity of $0-10 \mathrm{~cm}$ soil depth was greater as compared to that of $10-20 \mathrm{~cm}$ and $20-30$ $\mathrm{cm}$ depths. Generally, the increase in bulk density with depth induced a decrease in $\mathrm{HC}$ of subsurface soils (Table 4).

When the results obtained after soybean harvested (November-2008) were compared, the highest $\mathrm{HC}$ values of $0-10 \mathrm{~cm}$ and $10-20 \mathrm{~cm}$ depths were obtained with conventional tillage with residue incorporated in the soil (CTS) $\left(9.19 \times 10^{-6} \mathrm{~m} \mathrm{~s}^{-1}, \quad 8.68 \times 10^{-6} \mathrm{~m} \mathrm{~s}^{-1}\right)$ and conventional tillage with residue burned (CTB) $\left(9.02 \times 10^{-6} \mathrm{~m} \mathrm{~s}^{-1}, 8.40 \times 10^{-6} \mathrm{~m} \mathrm{~s}^{-1}\right)$. NT systems yielded the lowest $\mathrm{HC}$ values. Saturated hydraulic conductivity was increased with increasing the intensity and depth of the tillage operation to prepare the seed bed for the first and the second crops. Therefore, the effect of tillage systems on $\mathrm{HC}$ after the fourth application was prominent at all depths after soybean harvest.

Hydraulic conductivities in CTS and CTB applications were greater compared with the other tillage systems. Reduced and no-tillage applications (RNT or NT) induced to decrease 
Table 4-Effect of different tillage practices on saturated hydraulic conductivity and bulk density for each year and depth

Çizelge 4-Farklı toprak işleme uygulamalarının doymuş hidrolik iletkenlik ve hacim ağırlı̆ı̆na etkileri

\begin{tabular}{|c|c|c|c|c|c|}
\hline \multirow{2}{*}{$\begin{array}{l}\text { Tillage } \\
\text { Treatments }^{*}\end{array}$} & \multirow{2}{*}{$\begin{array}{c}\text { Depth, } \\
\mathrm{cm}\end{array}$} & \multicolumn{2}{|c|}{ Bulk density, $\mathrm{Mg} \mathrm{m}^{-3}$} & \multicolumn{2}{|c|}{ Hydraulic cond., $10^{-6} \mathrm{~m} \mathrm{~s}^{-1}$} \\
\hline & & $\begin{array}{c}\text { Maize } \\
\text { (October 2007) }\end{array}$ & $\begin{array}{c}\text { Soybean } \\
\text { (October 2008) }\end{array}$ & $\begin{array}{c}\text { Maize } \\
\text { (October 2007) }\end{array}$ & $\begin{array}{c}\text { Soybean } \\
\text { (October 2008) }\end{array}$ \\
\hline CTS & $0-10$ & $1.24 \pm 0.08^{\dagger}$ & $1.26 \pm 0.04$ & $9.49 \pm 0.78 \mathrm{a}$ & $9.19 \pm 0.49$ \\
\hline CTB & $0-10$ & $1.24 \pm 0.03$ & $1.30 \pm 0.03$ & $6.61 \pm 0.14 \mathrm{c}$ & $9.02 \pm 1.20$ \\
\hline RTD & $0-10$ & $1.30 \pm 0.06$ & $1.31 \pm 0.01$ & $7.64 \pm 0.62 \mathrm{abc}$ & $8.30 \pm 0.60$ \\
\hline RTR & $0-10$ & $1.32 \pm 0.03$ & $1.32 \pm 0.02$ & $8.58 \pm 0.99 \mathrm{ab}$ & $8.45 \pm 0.22$ \\
\hline RNT & $0-10$ & $1.33 \pm 0.05$ & $1.38 \pm 0.02$ & $7.02 \pm 0.66 \mathrm{bc}$ & $7.41 \pm 0.40$ \\
\hline NT & $0-10$ & $1.32 \pm 0.05$ & $1.40 \pm 0.02$ & $5.81 \pm 0.63 \mathrm{c}$ & $6.93 \pm 0.85$ \\
\hline CTS & $10-20$ & $1.33 \pm 0.06$ & $1.27 \pm 0.03$ & $8.24 \pm 0.95 \mathrm{a}$ & $8.68 \pm 0.63$ \\
\hline CTB & $10-20$ & $1.32 \pm 0.01$ & $1.31 \pm 0.04$ & $6.92 \pm 0.66 \mathrm{a}$ & $8.40 \pm 0.71$ \\
\hline RTD & $10-20$ & $1.36 \pm 0.07$ & $1.32 \pm 0.02$ & $7.89 \pm 0.99 \mathrm{a}$ & $6.97 \pm 0.12$ \\
\hline RTR & $10-20$ & $1.38 \pm 0.02$ & $1.32 \pm 0.03$ & $7.04 \pm 0.80 \mathrm{a}$ & $7.67 \pm 0.57$ \\
\hline RNT & $10-20$ & $1.40 \pm 0.02$ & $1.39 \pm 0.01$ & $6.74 \pm 1.08 \mathrm{a}$ & $6.47 \pm 0.48$ \\
\hline NT & $10-20$ & $1.34 \pm 0.03$ & $1.40 \pm 0.02$ & $6.29 \pm 0.10 \mathrm{a}$ & $6.41 \pm 0.72$ \\
\hline CTS & $20-30$ & $1.39 \pm 0.02$ & $1.29 \pm 0.02$ & $5.04 \pm 0.04 \mathrm{~b}$ & $7.20 \pm 0.15$ \\
\hline СТВ & $20-30$ & $1.40 \pm 0.03$ & $1.31 \pm 0.02$ & $7.21 \pm 0.65 \mathrm{a}$ & $5.92 \pm 0.30$ \\
\hline RTD & $20-30$ & $1.37 \pm 0.08$ & $1.34 \pm 0.01$ & $4.53 \pm 0.20 \mathrm{bc}$ & $6.44 \pm 0.07$ \\
\hline RTR & $20-30$ & $1.41 \pm 0.02$ & $1.35 \pm 0.03$ & $4.58 \pm 0.18 \mathrm{bc}$ & $6.11 \pm 0.60$ \\
\hline RNT & $20-30$ & $1.41 \pm 0.05$ & $1.40 \pm 0.02$ & $4.58 \pm 0.03 \mathrm{bc}$ & $6.04 \pm 0.25$ \\
\hline NT & $20-30$ & $1.39 \pm 0.06$ & $1.42 \pm 0.01$ & $3.84 \pm 0.48 \mathrm{c}$ & $5.92 \pm 0.36$ \\
\hline \multicolumn{6}{|c|}{ Main effects (Means) } \\
\hline CTS & & $1.32 \pm 0.09$ & $1.28 \pm 0.03 \mathrm{c}$ & $7.59 \pm 2.08 \mathrm{a}$ & $8.36 \pm 0.98 \mathrm{a}$ \\
\hline CTB & & $1.32 \pm 0.10$ & $1.31 \pm 0.02 \mathrm{bc}$ & $6.91 \pm 0.54 \mathrm{ab}$ & $7.78 \pm 1.59 \mathrm{ab}$ \\
\hline RTD & & $1.34 \pm 0.08$ & $1.32 \pm 0.02 \mathrm{~b}$ & $6.68 \pm 1.73 \mathrm{ab}$ & $7.23 \pm 0.89 \mathrm{bc}$ \\
\hline RTR & & $1.37 \pm 0.06$ & $1.33 \pm 0.03 \mathrm{~b}$ & $6.73 \pm 1.86 \mathrm{ab}$ & $7.41 \pm 1.12 \mathrm{bc}$ \\
\hline RNT & & $1.38 \pm 0.07$ & $1.39 \pm 0.02 \mathrm{a}$ & $6.11 \pm 1.32 \mathrm{bc}$ & $6.64 \pm 0.69 \mathrm{~cd}$ \\
\hline NT & & $1.34 \pm 0.06$ & $1.41 \pm 0.02 \mathrm{a}$ & $5.31 \pm 1.19 \mathrm{c}$ & $6.42 \pm 0.73 \mathrm{~d}$ \\
\hline & $0-10 \mathrm{~cm}$ & $1.29 \pm 0.12 \mathrm{~b}$ & $1.33 \pm 0.06 \mathrm{~b}$ & $7.52 \pm 1.39 \mathrm{a}$ & $8.22 \pm 1.03 \mathrm{a}$ \\
\hline & $10-20 \mathrm{~cm}$ & $1.35 \pm 0.12 \mathrm{a}$ & $1.34 \pm 0.06 \mathrm{ab}$ & $7.18 \pm 0.98 \mathrm{a}$ & $7.43 \pm 1.03 \mathrm{~b}$ \\
\hline & $20-30 \mathrm{~cm}$ & $1.39 \pm 0.12 \mathrm{a}$ & $1.35 \pm 0.06 \mathrm{a}$ & $4.96 \pm 1.13 b$ & $6.27 \pm 0.54 \mathrm{c}$ \\
\hline \multicolumn{6}{|l|}{$P$ values } \\
\hline Tillage & & 0.060 & 0.000 & 0.000 & 0.000 \\
\hline Depth & & 0.000 & 0.019 & 0.000 & 0.000 \\
\hline Tillage $\times$ Depth & & 0.833 & 0.998 & 0.000 & 0.054 \\
\hline
\end{tabular}

${ }^{*}$ CTS: Conventional tillage with residue, CTB: Conventional tillage with residues burned, RTD: Reduced tillage with heavy tandem disc harrow, RTR: Reduced tillage with rotary tiller, RNT: Reduced tillage with heavy tandem disc harrow for the fist crop+no-tillage for the second crop, NT: No tillage.

${ }^{\dagger}$ The numbers following \pm indicate standard deviation.

${ }^{\mathrm{a}-\mathrm{d}}$ : Values in a same column followed by different letter are significantly different (Tukey, $P \leq 0.05$ ).

hydraulic conductivity compared with conventional tillage methods (Table 4). Some of results reported by others also agreed to ours. Heard et al (1988) attributed the greater hydraulic conductivity in conventionally tilled soils to greater number of voids and cracks caused by tillage implement. However, Chan \& Mead (1989) noted that no-tilled soils had greater hydraulic conductivity than tilled soils. On the other hand, no differences in hydraulic conductivity between conventional tillage, minimum tillage and no-tillage soils were reported by Horne et al 1992 . We attributed the lower hydraulic conductivity in NT and RNT treatments to high proportion of swelling clays in our soils; greater bulk density (Table 4), and 
greater penetration resistance under no-tillage and reduced tillage (Table 5 and Figure 1). Dawidovsky \& Koolen (1987), Kutilek \& Nielsen (1994), and Celik et al (2010) reported the soil compaction causes to decrease saturated hydraulic conductivity in soils. High bulk density values obtained under no-tillage and reduced tillage systems are the indications of soil compaction (Abu-Hamdeh 2003), and might be the cause of low hydraulic conductivity obtained in no-tillage and reduced tillage systems (Table 4).

When the results of 2008 were compared, the average values of $\mathrm{HC}$ for CTS and CTB were higher than in NT and RNT. These findings were in agreement with the results reported by Obi \& Nnabude (1988), Miller et al (1998), and Rahman et al (2008) who reported significantly higher values for saturated hydraulic conductivity in CT than NT and reduced tillage. The inconsistent results of soil physical and hydraulic properties under different tillage systems may be related to the transitory nature of soil structure after tillage, site history, initial and final water content, the time of sampling and the extent of soil disturbances (Azooz \& Arshad 1996).

\subsection{Soil penetration resistance}

Differences in soil moisture content between tillage treatments at the time of penetration measurements were insignificant $(\mathrm{P}>0.05)$ and no adjustments to the penetration data were therefore necessary (Table 3 ). Hence, penetration resistance was accepted a good representative parameter for soil compaction under different tillage treatments. Average penetration resistance values of $0-10 \mathrm{~cm}$, $11-20 \mathrm{~cm}, 21-30 \mathrm{~cm}$, and $31-45 \mathrm{~cm}$ soil depths for different tillage treatments were given in Table 5 . The penetration resistance curves determined for $0-45 \mathrm{~cm}$ soil depth were also presented in Figure 1.

Tillage treatments and soil depth had significant $(P<0.01)$ effects on soil penetration resistance in 2007 and 2008 (Table 5). Tillage treatments increased penetration resistance at all soil depths for all years compared to initial measurements. Similar to $\mathrm{HC}$ values, tillage $\times$ depth interaction effects on the soil penetration resistance was found statistically significant $(P<0.05)$ for 2007, but not $(P=0.066)$ for 2008 .

The penetration resistance of three layers (11$20 \mathrm{~cm}, 21-30 \mathrm{~cm}$ and $31-45 \mathrm{~cm}$ ) were the highest under no-tillage and reduced tillage (RNT, RTR and RTD), and the lowest values of penetration resistance were obtained in conventional tillage (CTS and CTB) methods after maize harvest (Table 5). The penetration resistances of four layers were the highest under no-tillage and reduced tillage, while the lowest values were obtained in CTS and CTB methods after soybean harvest, respectively (Table 5). There was no difference between penetration resistances in conservation tillage treatments (RTD, RTR, RNT and NT) in 2008.

The use of chisel that tills about 35 to $38 \mathrm{~cm}$ in second crop corn and soybean probably lowered the penetration resistance in CTB than in CTS especially at $21-45 \mathrm{~cm}$ depth. The increase in intensity and depth of tillage practices resulted in low penetration resistance values at all depths (Table 5, and Figure 1).

Reduced and especially no-tillage treatments caused to increase penetration resistance compared with conventional tillage methods. Our results are in good agreement with those of Schwartz et al (2003), who reported that NT practices increased the penetration resistance of the soil when compared to CT and RT. Dalal (1992) also found greater compaction under NT than CT in a Vertisol. Similar results of greater penetration resistance in NT than CT were reported by Moret \& Arrue (2007), and Alvarez et al (2009).

The increase in bulk density and penetration resistance under reduced tillage and no-tillage (Table 4 and Table 5) indicated probable soil compactions. Bulk density and penetration resistance were used to characterize the soil compaction which influences the structural characteristics and functions of soils (Hakansson \& Lipiec 2000; Abu-Hamdeh 2002; Celik et al 2010). Lower bulk density and penetration resistance obtained in conventional tillage (CTS and $\mathrm{CTB}$ ) might be attributed to short term 
Table 5-Effect of different tillage practices on penetration resistance for each year and depth Çizelge 5- Farklı toprak işleme uygulamalarının penetrasyon direncine etkileri

\begin{tabular}{|c|c|c|c|}
\hline \multirow{2}{*}{$\begin{array}{l}\text { Tillage } \\
\text { Treatments }\end{array}$} & \multirow{2}{*}{$\begin{array}{l}\text { Depth, } \\
\mathrm{cm}\end{array}$} & \multicolumn{2}{|c|}{ Mean Penetration Resistance, $M P a$} \\
\hline & & Maize (October 2007) & Soybean (October 2008) \\
\hline CTS & $0-10$ & $1.14 \pm 0.53^{\dagger} \mathrm{a}$ & $1.13 \pm 0.36$ \\
\hline СТВ & $0-10$ & $1.48 \pm 0.69 \mathrm{a}$ & $1.04 \pm 0.36$ \\
\hline RTD & $0-10$ & $1.34 \pm 0.76 \mathrm{a}$ & $1.27 \pm 0.52$ \\
\hline RTR & $0-10$ & $1.62 \pm 0.82 \mathrm{a}$ & $1.37 \pm 0.43$ \\
\hline RNT & $0-10$ & $1.34 \pm 0.81 \mathrm{a}$ & $1.50 \pm 0.48$ \\
\hline NT & $0-10$ & $1.78 \pm 0.81 \mathrm{a}$ & $1.72 \pm 0.56$ \\
\hline CTS & $11-20$ & $1.93 \pm 0.68 \mathrm{e}$ & $1.44 \pm 0.26$ \\
\hline CTB & $11-20$ & $2.05 \pm 0.52 \mathrm{~d}$ & $1.29 \pm 0.29$ \\
\hline RTD & $11-20$ & $2.31 \pm 0.51 \mathrm{c}$ & $1.66 \pm 0.39$ \\
\hline RTR & $11-20$ & $2.33 \pm 0.64 \mathrm{c}$ & $1.63 \pm 0.56$ \\
\hline RNT & $11-20$ & $2.46 \pm 0.52 \mathrm{~b}$ & $1.69 \pm 0.52$ \\
\hline NT & $11-20$ & $2.67 \pm 0.22 \mathrm{a}$ & $1.79 \pm 0.10$ \\
\hline CTS & $21-30$ & $2.18 \pm 0.82 \mathrm{~d}$ & $1.46 \pm 0.11$ \\
\hline CTB & $21-30$ & $1.92 \pm 0.22 \mathrm{e}$ & $1.36 \pm 0.11$ \\
\hline RTD & $21-30$ & $2.28 \pm 0.26 \mathrm{bc}$ & $1.72 \pm 0.96$ \\
\hline RTR & $21-30$ & $2.25 \pm 0.40 \mathrm{~cd}$ & $1.65 \pm 0.71$ \\
\hline RNT & $21-30$ & $2.34 \pm 0.34 \mathrm{~b}$ & $1.72 \pm 0.56$ \\
\hline NT & $21-30$ & $2.71 \pm 0.69 \mathrm{a}$ & $1.71 \pm 0.48$ \\
\hline CTS & $31-45$ & $2.44 \pm 0.10 \mathrm{~cd}$ & $1.88 \pm 0.12$ \\
\hline СТВ & $31-45$ & $1.96 \pm 0.53 \mathrm{e}$ & $1.84 \pm 0.13$ \\
\hline RTD & $31-45$ & $2.40 \pm 0.95 \mathrm{~d}$ & $1.99 \pm 0.74$ \\
\hline RTR & $31-45$ & $2.55 \pm 0.10 \mathrm{c}$ & $2.00 \pm 0.90$ \\
\hline RNT & $31-45$ & $2.69 \pm 0.14 \mathrm{~b}$ & $2.11 \pm 0.14$ \\
\hline NT & $31-45$ & $2.89 \pm 0.88 \mathrm{a}$ & $2.00 \pm 0.92$ \\
\hline \multicolumn{4}{|c|}{ Main effects (Means) } \\
\hline CTS & & $1.96 \pm 0.57 \mathrm{~cd}$ & $1.52 \pm 0.35 \mathrm{~b}$ \\
\hline CTB & & $1.86 \pm 0.40 \mathrm{~d}$ & $1.43 \pm 0.37 \mathrm{~b}$ \\
\hline RTD & & $2.10 \pm 0.56 \mathrm{bc}$ & $1.69 \pm 0.37 \mathrm{a}$ \\
\hline RTR & & $2.22 \pm 0.53 \mathrm{~b}$ & $1.70 \pm 0.32 \mathrm{a}$ \\
\hline RNT & & $2.24 \pm 0.66 \mathrm{~b}$ & $1.79 \pm 0.34 \mathrm{a}$ \\
\hline NT & & $2.54 \pm 0.59 \mathrm{a}$ & $1.83 \pm 0.30 \mathrm{a}$ \\
\hline & $0-10 \mathrm{~cm}$ & $1.45 \pm 0.04 \mathrm{c}$ & $1.34 \pm 0.03 \mathrm{c}$ \\
\hline & $11-20 \mathrm{~cm}$ & $2.29 \pm 0.04 \mathrm{~b}$ & $1.58 \pm 0.03 \mathrm{~b}$ \\
\hline & $21-30 \mathrm{~cm}$ & $2.28 \pm 0.04 \mathrm{~b}$ & $1.60 \pm 0.03 \mathrm{~b}$ \\
\hline & $31-45 \mathrm{~cm}$ & $2.49 \pm 0.03 \mathrm{a}$ & $1.97 \pm 0.02 \mathrm{a}$ \\
\hline \multicolumn{4}{|l|}{$P$ values } \\
\hline Tillage & & 0.000 & 0.000 \\
\hline Depth & & 0.000 & 0.000 \\
\hline Tillage $\times$ Depth & & 0.018 & 0.066 \\
\hline
\end{tabular}

${ }^{*}$ CTS: Conventional tillage with residue, CTB: Conventional tillage with residues burned, RTD: Reduced tillage with heavy tandem disc harrow, RTR: Reduced tillage with rotary tiller, RNT: Reduced tillage with heavy tandem disc harrow for the fist crop+no-tillage for the second crop, NT: No tillage.

${ }^{\dagger}$ The numbers following \pm indicate standard deviation.

$\stackrel{\mathrm{a}-\mathrm{e}}{\mathrm{a}}$ : Values in a same column followed by different letter are significantly different (Tukey, $P \leq 0.05$ ).

loosening effect of tillage, and incorporation of harvest in 2007, the average penetration resistance stubble/stover to soil surface layers.

The penetration resistance values were lower in CTB compared to CTS especially at $21-45 \mathrm{~cm}$, due to the use of the chisel for CTB after the second crop at 35-38 cm depth. After the corn for $0-45 \mathrm{~cm}$, under NT was $29 \%$ and $36 \%$ higher than the CTS and CTB, respectively. Similarly, after soybean harvesting in 2008 the penetration resistance under NT was $20 \%$ and $28 \%$ higher than the CTS and CTB, respectively. 


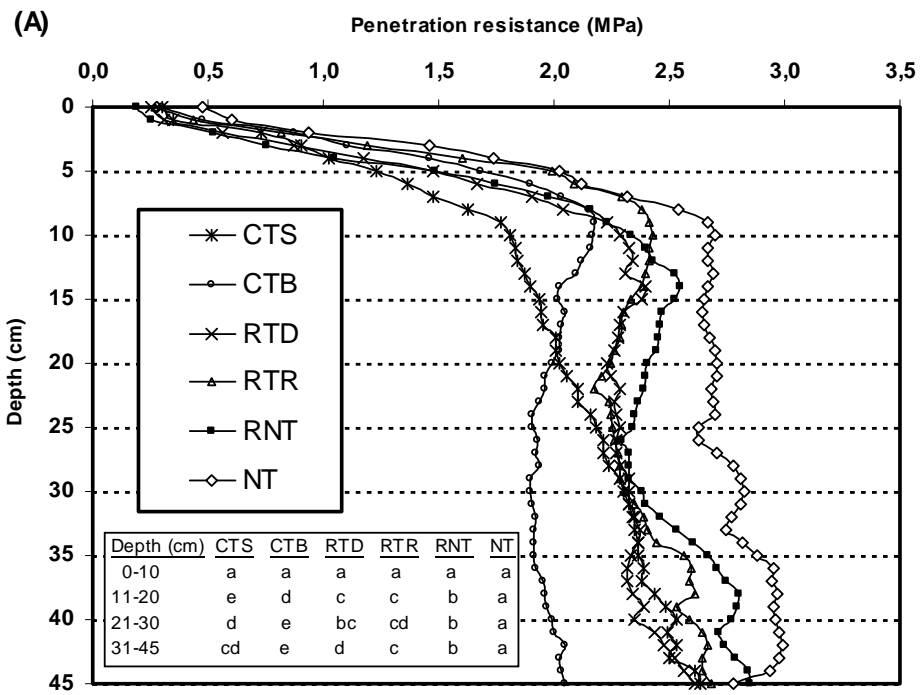

(B)

Penetration resistance (MPa)

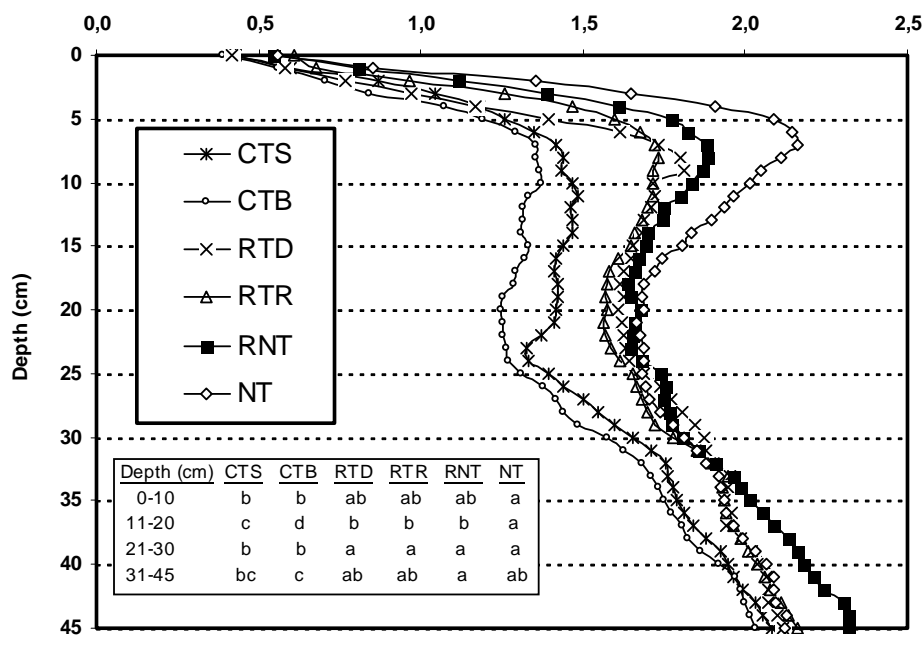

Figure 1-Effects of tillage on soil penetration resistance at 0-45 cm soil depth of (A) after maize and (B) after soybean. CTS: Conventional tillage with residue, CTB: Conventional tillage with residues burned, RTD: Reduced tillage with heavy tandem disc harrow, RTR: Reduced tillage with rotary tiller, RNT: Reduced tillage with heavy tandem disc harrow for the fist crop+no-tillage for the second crop, NT: No tillage. Values followed by the same letter in the same depth are not significantly different (Tukey, $\boldsymbol{P} \leq \mathbf{0 . 0 5})$.

Şekil 1- Toprak işleme uygulamalarının misır sonrası (A) ve soya sonrası (B) 0-45 cm toprak derinliğinde toprak penetrasyon direncine etkileri. CTS: Anızlı geleneksel toprak işleme, CTB: anızları yakılmış geleneksel toprak işleme, RTD: ă̆ır diskli tırmıklı azaltılmış toprak işleme, RTR: rototillerli azaltılmış toprak işleme, RNT: birinci ürün için ă̆ır diskli tırmıklı azaltılmış işleme + ikinci ürün için doğrudan ekim ve NT: doğrudan ekimi 


\section{Conclusion}

Conventional tillage for two years in wheat-corn and wheat-soybean rotations resulted in higher saturated hydraulic conductivity than no-tillage and reduced tillage for Arik heavy clayey soils (Typic Haploxererts), and this was attributed increased bulk density and penetration resistance in no-tilled and reduced tilled soils. The hydraulic conductivity values under NT in 2007 and 2008 were lower $20 \%$ and $30 \%$ at $0-30 \mathrm{~cm}$ depth than that in CTS, respectively.

Incorporating the residue into soils in CTS generally resulted in a greater hydraulic conductivity compared to residue burned (CTB) at $0-10 \mathrm{~cm}$ and $10-20 \mathrm{~cm}$. The bulk density and penetration resistance were significantly greater under no-tillage and reduced tillage than those under conventional tillage at all depths studied. The soil bulk density and penetration resistance values were lower on the surface layers and increased with depth under all tillage methods. The hydraulic conductivity was improved in tilled soils due to decreased soil compaction and soil loosing.

The reduced tillage practices (RTD, RTR and RNT) had detrimental effects depending on sampling periods and soil depth, and the soil compaction under RNT was greater as compared to the others. Despite the higher values obtained for bulk density and penetration resistance in notillage compared to the reduced tillage treatments at $0-10 \mathrm{~cm}$ and $10-20 \mathrm{~cm}$, there were no significant differences between the reduced tillage treatments (RTD, RTR and RNT). Our results suggested that since saturated hydraulic conductivity, penetration resistance, and bulk density were adversely affected, no-tillage and reduced tillage should be applied cautiously in a high clay content soil under a semi-arid climate.

\section{Acknowledgement}

We thank the TUBITAK (The Scientific and Technological Research Council of Turkey) for financial support for the project (Grant No: TOVAG 106O023), which allowed this work to be carried out.

\section{References}

Abu-Hamdeh N H (2002). Effect of soil manipulation and other field parameters on soil physical properties 12th ISCO Conference, Beijing

Abu-Hamdeh N H (2003). Soil compaction and root distribution for okra as affected by tillage and vehicle parameters. Soil and Tillage Research 74(1): 25-35

Alvarez C R, Taboada M A, Gutierrez Boem F H, Bono A, Fernandez P L \& Prystupa P (2009). Topsoil properties as affected by tillage systems in the Rolling Pampa Region of Argentina. Soil Science Society of America Journal 73(4): 1242-1250

ASAE (1994). Soil cone penetrometers. S313.2 in Standards Engineering Practices Data, ASAE Standards, St. Joseph, MI

Azooz R H \& Arshad M A (1996). Soil infiltration and hydraulic conductivity under long-term no-tillage and conventional tillage systems. Canadian Journal of Soil Science 76(2): 143-152

Benjamin J G (1993). Tillage effects on near-surface soil hydraulic properties. Soil and Tillage Research 26(4): 277-288

Bhattacharyya R, Prakash V, Kundu S \& Gupta H S (2006). Effect of tillage and crop rotations on pore size distribution and soil hydraulic conductivity in sandy clay loam soil of the Indian Himalayas. Soil and Tillage Research 86(2): 129-140

Blake G R \& Hartge K H (1986). Bulk density. In: Klute, A. (Ed.), Methods of Soil Analysis. Part 1. Physical and Mineralogical Methods, 2nd ed. Agron. Monogr. 9. ASA-SSA, Madison, WI, pp: 363-375

Blevins R L, Thomas G W, Smith M S, Frye W W \& Cornelius P L (1983). Changes in soil properties after 10 years non-tilled and conventionally tilled corn. Soil and Tillage Research 3(2): 135-146

Celik I, Ortas I, Barut Z B, Gok M, Sarıev A, Demirbas A, Akpinar C \& Tulun Y (2009). Effects of different soil tillage systems on soil quality parameters and crop yields. Final report of the TUBITAK project (The Scientific and Technological Research Council of Turkey, Grant No: 1060023) pp:163 (in Turkish)

Celik I, Gunal H, Budak M \& Akpinar C (2010). Effects of long-term organic and mineral fertilizers on bulk density and penetration resistance in semiarid Mediterranean soil conditions. Geoderma 160(2): 236-243 
Chan K Y \& Heenan D P (1993). Surface hydraulic properties of a red earth under continuous cropping with different management practices. Australian Journal of Soil Research 31(1): 13-24

Chan K Y \& Mead J A (1989). Water movement and macroporosity of an Australian alfisol under different tillage and pasture conditions. Soil and Tillage Research 14(4): 301-310

Dalal R C (1992). Long-term trends in total nitrogen of a Vertisol subjected in zero tillage, nitrogen application and stubble retention. Australian Journal of Soil Research 30(2): 223-231

Dam R F, Mehdi B B, Burgess M S E, Madramootoo C A, Mehuys G R \& Callum I R (2005). Soil bulk density and crop yield under eleven consecutive years of corn with different tillage and residue practices in a sandy loam soil in central Canada. Soil and Tillage Research 84: 41-53

Dao T H. 1996. Tillage system and crop residue effects on surface compaction of a Paleustill. Agronomy Journal 88: 141-148

Datiri B C \& Lowery B (1991). Effects of conservation tillage on hydraulic properties of a Griswold silt loam soil. Soil and Tillage Research 21(3-4): 257271

Dawidowsky J B \& Koolen A J (1987). Changes in soil water suction, conductivity and dry strength during deformation of wet undisturbed samples. Soil and Tillage Research 9(2): 169-180

Green R T, Ahuja L R \& Benjamin J G (2003). Advances and challenges in predicting agricultural management effects on soil hydraulic properties. Geoderma 116(1-2): 3-27

Hakansson I \& Lipiec J (2000). A review of the usefulness of relative bulk density values in studies of structure and compaction. Soil and Tillage Research 53(2): 71-85

Heard J R, Kladivko E J \& Mannering J V (1988). Soil macroporosity, hydraulic conductivity and air permeability of silty soils under long-term conservation tillage in Indiana. Soil and Tillage Research 11(1): 1-18

Horne D J, Ross C W \& Hughes K A (1992). 10 years of a maize oats rotation under three tillage systems on a silt loam in New Zealand. 1. A comparison of some soil properties. Soil and Tillage Research 22(1-2): 131-143

Johnson C E \& Bailey A C (2002). Soil compaction. In advances in soil dynamics, Volume 2, pp.155-178. St. Joseph, Mich.: ASAE
Kanwar R S (1989). Effect of tillage system on the variability of soil water tensions and water content. Trans. ASAE 32(2): 605-610

Karlen D L, Wollenhaupt N C, Erbach D C, Berry E C, Swan J B, Eash N S \& Jordahl JL (1994). Crop residue effects on soil quality following 10 years of no-till corn. Soil and Tillage Research 31(2-3): 149-167

Klute A \& Dirksen C (1986). Hydraulic conductivity and diffusivity: In: Klute, A. (Ed.), Methods of Soil Analysis. Part 1. Physical and Mineralogical Methods, 2nd ed. Agron. Monogr. 9. ASA-SSA, Madison, WI, pp: 687-734

Klute A (1982). Tillage effects on the hydraulic properties of soil: a review. In: Unger, P.W., Van Doren, Jr., D.M. (Eds.), Predicting Tillage Effects on Soil Physical Properties and Processes, ASA Spec. Publ. No. 44. ASA, Madison, WI, pp. 29-44

Kutilek M \& Nielsen D R (1994). Soil Hydrology. Catena Verlag, Cremlingen-Destedt, 370 pp. (ISBN 3-923381-26-3)

Liebig M A, Tanaka D L \& Wienhold B J (2004). Tillage and cropping effects on soil quality indicators in the northern Great Plains. Soil and Tillage Research 78(2): 131-141

Mamman E \& Ohu J O (1998). The effect of tractor traffic on air permeability and millet production in a sandy loam soil in Nigeria. Ife Journal of Technology 8(1): 1-7

McGarry D, Bridge B J \& Radford B J (2000). Contrasting soil physical properties after zero and traditional tillage of an alluvial soil in the semi-arid subtropics. Soil and Tillage Research 53(2): 105115

Meek B D, Rechel E A, Cater L M, DeTar W R \& Urie A L (1992). Infiltration rate of a sandy loam soil: effets of traffic, tillage, and plant roots. Soil Science Society of America Journal 56: 908-913

Miller J J, Kokko E G \& Kozub G C (1998). Comparison of porosity in a chernozemic clay loam soil under long-term conventional tillage and notill. Canadian Journal of Soil Science 78(4): 619629

Moret D \& Arrue J L (2007). Dynamics of soil hydraulic properties during fallow as affected by tillage. Soil and Tillage Research 96(1-2): 103-113

Obi M E \& Nnabude P C (1988). The effect of different management practices on the physical properties of a sandy loam soil in southern Nigeria. Soil and Tillage Research 12(1): 81-90 
Osunbitan J A, Oyedele D J \& Adekalu K O (2005). Tillage effects on bulk density, hydraulic conductivity and strength of a loamy sand soil in southwestern Nigeria. Soil and Tillage Research 82(1): 57-64

Radford B J \& Nielsen R G H (1985). Comparison of pres wheels, seed soaking and water injection as aids to sorghum and sunflower establishment in Queensland. Australian Journal of Experimental Agriculture 25(3): 656-664

Rahman M H, Okubo A, Sugiyama S \& Mayland H F (2008). Physical, chemical and microbiological properties of an Andisol as related to land use and tillage practice. Soil and Tillage Research 101: 1019

Raper R L \& Kirby J M (2005). Soil Compaction: How to do it, Undo it, or Avoid doing it. ASABE Distinguished Lecture Series No. 30, pp:1-14

Roscoe R \& Buurman P (2003). Tillage effects on soil organic matter in density fractions of a Cerrado Oxisol. Soil and Tillage Research 70(2): 107-119

Schwartz R C, Evett S R \& Unger P W (2003). Soil hydraulic proper-ties of cropland compared with reestablished and native grassland. Geoderma 116(1-2): 47-60

Sharratt B, Zhang M \& Sparrow S (2006). Twenty years of tillage research in subarctic Alaska I. Impact on soil strength, aggregation, roughness, and residue cover. Soil and Tillage Research 91(1-2): 75-81

Sillon J F, Richard G \& Cousin I (2003). Tillage and traffic effects on soil hydraulic properties and evaporation. Geoderma 116(1-2): 29-46

Soil Survey Staff (1999). Soil taxonomy: a basic system of soil classification for making and interpreting soil surveys, 2nd edition. Agriculture Handbook, vol:435 pp:326

Tebrügge F \& Düring R A (1999). Reducing tillage intensity-a review of results from a long-term study in Germany. Soil and Tillage Research 53: 15-28

Wu L, Swan J B, Paulson W H \& Randall G W (1992). Tillage effects on measured soil hydraulic properties. Soil and Tillage Research 25: 17-33

$\mathrm{Xu}$ D \& Mermoud A (2001). Topsoil properties as affected by tillage practices in North China. Soil and Tillage Research 60(1): 11-19

Zhang S, Grip H \& Lövdahl L (2006). Effect of soil compaction on hydraulic properties of two loess soils in China. Soil and Tillage Research 90(1-2): $117-125$ 